\title{
Article
}

\section{Accessing occupational health services in the Southern African Development community region}

\author{
*Daniel M. Masekameni ${ }^{1}$, Dingani Moyo ${ }^{1,2,3}$, N. Khoza ${ }^{4}$, C. Chamdimba ${ }^{4}$
}

\author{
${ }^{1}$ Occupational Health Division, School of Public Health, University of the Witwatersrand, Parktown, \\ Johannesburg, 2193. danielmasekameni@gmail.com \\ ${ }^{2}$ Midlands State University, Faculty of Social Sciences, Gweru, Zimbabwe \\ ${ }^{3}$ Baines Occupational Health Services and Safety Group, Harare, Zimbabwe. moyod@iwayafrica.co.zw \\ ${ }^{4}$ Health Division, Programme Delivery and Coordination Directorate, African Union Development Agency- \\ New Partnership for Africa's Development (AUDA-NEPAD). NormanK@nepad.org \\ * Correspondence: danielmasekameni@gmail.com +2711 7172355
}

\begin{abstract}
Only $15 \%$ of the global population has access to occupational safety and health services. In Africa only $5 \%$ of employees working from major establishments, have access to occupational health services (OHS). Access to primary health care (PHC) services is addressed in many settings and inclusion of OHS in these facilities might increase efficiency in preventing occupational diseases. A cross-sectional study was conducted in four SADC countries aiming at assessing the availability of OHS at PHC facilities and the organization of OHS. We conducted a literature review to assess the provision and organization of OHS services. In addition to the review, a total of 23 doctors from PHC facilities were interviewed using questionnaires in order to determine the availability of OHS and training. Consultations with heads of ministries were done in four SADC countries. Results showed that in the SADC region, OHS are fragmented and lack a comprehensive approach. In addition, out of 23 PHC facilities only two (13\%) provided occupational health and PHC. However, OHS provided at PHC facilities were limited to TB screening and audiometric testing. Our study showed a huge inadequacy of trained occupational health practitioners. This study supports the World Health Organization's advocacy of integrating OHS at PHC level.
\end{abstract}

Keywords: Occupational health services, mining, primary health clinics, labour

\section{Introduction}

Recently, the International labour Organization (ILO) indicated that about 2.8 million men and women die annually due to work related problems [1]. Furthermore, about $86 \%$ of the total mortalities are attributed to occupational health related illnesses [2,3]. Over the past two decades, industrial activities have increased leading to the introduction of new hazards and new health outcomes [4]. The consequences of new hazards are likely to be more catastrophic in developing countries due to weaker technological advancement in occupational hygiene monitoring and occupational diseases diagnosis $[1,5,6]$. This suggests a need to develop mechanisms for practitioners in developing countries to advance their knowledge and understanding on the basic occupational health service package.

In the SADC region, the majority of people are employed in the mining sector [7]. Studies suggest that about half of the world's vanadium, platinum, and diamonds originate in the region, while $36 \%$ of gold and $20 \%$ of cobalt are produced in this region [8]. Since mining operations have been associated with increased exposure to pollutants leading to several health effects, the SADC region is considered 
amongst the top high risk countries [9]. Exposure to fine mine dust has increased the risk of illnesses such as silicosis, coal pneumoconiosis, cardiovascular illness and tuberculosis $[8,10,11]$.

Access to occupational health services and primary health care services can be one of the most appropriate ways of reducing associated health effects [7]. Though primary health care services are generally understood as a mandate of government to ensure universal health access mostly for the poor, this understanding needs to change [5,9]. OHS are often funded by industries but regulated by the government [12]. The two understandings on primary and occupational health services suggest that workers are not part of the general public nor are general public member's part of the working population.

In many developing countries there is an increasing challenge on accessing and providing OHS as the demand is on the rise due to employee's awareness programs [6,9]. In the SADC region, the provision of OHS is poorly regulated [10,13]. Furthermore, there is a shortage of trained and knowledgeable occupational health practitioners [14]. Therefore, it is imperative to develop other mechanisms to increase capacity in OHS. Such alternatives might include allocation of resources for training practitioners, establishing or review of legislative frameworks and adding OHS at primary health care centers $[1,15]$.

The connection of labour and health is anticipated as a vehicle to integrate primary health care and OHS [3]. Most current and ex-mine workers are in communities where access to occupational health services is poor but with good access to primary health care services which are widely distributed [8]. This presents a good opportunity of integrating OHS into the primary health care system. Therefore, an introduction of OHS in primary health care is envisaged as a vital tool for accelerating diagnosis and treatment of occupational diseases for those who are affected $[3,11]$.

Resolution WHA 60.26 “Workers' Health: Global Plan of Action”, calls for all member states to ensure coverage of all workers in both the formal and informal sectors across all working spaces with essential interventions and basic occupational health services for primary prevention of occupational and workrelated diseases and injuries [16]. It is therefore imperative that occupational health services are provided at primary health care levels.

Our study sought to evaluate the organization of OHS and determine the opportunities for integrating OHS into primary health care centers in four SADC countries: (Zambia, Malawi, Mozambique, and Lesotho). The objective of this study was to determine the need for future integration of OHS into the primary health care institutions in the SADC region. The study hypothesizes that there is limited OHS in primary health care facilities in the SADC region despite high economic growth in the mining sector. 


\section{Material and Methods}

\subsection{Methods}

The study areas consisted of four SADC countries: Lesotho, Malawi, Mozambique and Zambia. The study adopted a mixed methods approach in collecting data whereby a cross sectional study, literature review and consultations of ministry heads were carried out to acquire sufficient information to gain an insight on the arrangement and provision of OHS in the SADC region. Research articles and technical reports from the four countries were reviewed and analysed. Several databases which included Medscape/Medline, NIOSH, Science direct and the Social Science Citation Index were used to access journal articles. The literature review process was supplemented by surveys and completion of databases using customised templates, on OHS arrangements. Through the project host, African Union Development Agency (AUDA- NEPAD), consultations on OHS were made with several heads of ministries in the four project countries. We undertook a direct search of relevant journals in the fields of occupational medicine/health, industrial hygiene, environmental health and public health. We also checked the citation lists of the identified articles published on similar topics. Finally, we benefited from the helpful assistance of the project heads, inspectors and medical physicians in each of the four countries.

\subsection{Sampling population and data collection}

The selection of the four countries was influenced by the Southern African TB and Health Systems Strengthening (SATBHSS) project in the four project selected countries supported by the World Bank. A detailed desktop literature review of published literature was carried out in the African continent to gather data on the organization of occupational health and safety services. Reviewed literature included technical reports and scientific papers retrieved from article search engines such as PubMed, google scholar and science direct. Computerised search words were "occupational health, occupational health services, primary health care and occupational diseases. The authors then reviewed the obtained articles and technical reports for inclusion in the analysis. The first criterion was to read the article or report abstract to check if it contained the relevant information, while the second part involved reading the entire article or report. A total of 960 articles and 20 technical reports were extracted from the literature search engines. Approximately, 603 articles were rejected during the first round of the review, since the information was not relevant to the scope of the project. An additional 293 articles and repots were rejected in the second phase of the review due to non-compliance. Of 980 searched literature articles, only 80 articles and 4 reports were used in the final review. In the final review only 8 research articles and 3 technical reports were used to synthesise the results, since they highlighted OHS in SADC region. The search words such as occupational health and occupational diseases resulted in a large number of irrelevant literature which was finally rejected. Other reports and articles were rejected because they were not peer reviewed or validated before publishing. 
A total of 23 medical practitioners in Zambia were selected according to the districts where mining activities are concentrated. Each district hospital and clinic had one medical practitioner participating in the focus group discussion. A focused group discussion was held with a total of 23 medical practitioners in Zambia serving the mining communities. Semi structured questionnaires were selfadministered to the study participants for completion. The first part of the questionnaires comprised of close ended questions where the participants were limited to a "Yes or a No" answer, while the second part of the questionnaires comprised of open ended questions where the participants were given an opportunity to express their views.

Thirdly, a database on occupational health personnel which included occupational medical practitioners and occupational hygienists was requested from the four project countries. Information on occupational health services arrangement in the four project countries was obtained through a template which required information on the number of occupational health service professionals in each country. The template was completed by heads of the ministries of health, mines and labour comprising of of occupational health nurses (OHNs), occupational medical practitioners (OMPs) labour and mines safety and health inspectors, and occupational hygienists (OHs). Furthermore, the heads of ministries were required to indicate the actual targeted number of occupational health personnel required in addition to what was available.

\subsection{Data analysis}

Data from literature review was qualitatively analysed using themes extracted from different research findings. The results from the review were grouped according to themes based on similarities of findings from different studies conducted in five countries (Lesotho, Malawi, Mozambique, South Africa, and Zambia). Data obtained using questionnaires was exported into a Microsoft Excel 2016 version for further analysis. Incomplete or wrongly completed questionnaires were discarded. Results were tabulated and percentage calculations were based on the absolute 100 value resulting in the maximum percentage of 100 . No statistical analysis was carried out since the study did not seek to compare different situations but only described allocation of OHS, access and competencies.

\subsection{Study limitations}

The study sample size for the cross sectional study was from a single country, Zambia, out of the 4 SADC countries, which might not be representative of the entire populations. The study did not account for variability within countries and persons involved which might increase the uncertainty of the results. The study is only limited to describe access to OHS and does not include the characterization of institutional capacity, gap assessments and barriers in improving access. Furthermore, the study only focused on four SADC countries, but we do acknowledge that there are many countries in SADC. Only medical practitioners and heads of ministries constituted the sample population. This might present a limitation especially since nurses who are often the first contact in health facilities were excluded. The 
exclusion of the nurses was based on the funding structure which only accommodated medical practitioners. 


\section{Results}

In this section we have presented the study results in three different parts, the first part provided a review of OHS review in the SADC region. The second part reported the availability of occupational health professionals in four selected project countries, while the third part presented results from a Zambian case study.

\subsection{Organization of occupational health and safety services in the four countries}

In Table 1, several research peer reviewed journal articles and technical reports results were reviewed to assess the status of OHS arrangement and provision in SADC region. Almost all reviewed articles and reports indicated the need to strengthen OHS across the SADC region. Major highlights included increasing institutional capacity in training occupational health professionals, review of legislative framework, OHS financing and

Table 1: Results of literature review on OHS legislation and organization

\begin{tabular}{|l|l|l|l|}
\hline Author/s & Title & OHS objective & Key findings \\
\hline$[10]$ & Occupational health and safety in the Southern & $\begin{array}{l}\text { Moyo and colleagues found that } \\
\text { OHS in SADC lags in many areas, } \\
\text { while attention is mainly focused on } \\
\text { public health programs such as HIV } \\
\text { african Development Community }\end{array}$ & $\begin{array}{l}\text { OHS They further indicated that } \\
\text { most OHS are in the hands of } \\
\text { unqualified professionals in the field } \\
\text { of occupational medicine. The lack of } \\
\text { qualified } \\
\text { occupational health } \\
\text { practitioners was suggested to be }\end{array}$ \\
\hline
\end{tabular}


Peer-reviewed version available at Int. J. Environ. Res. Public Healith 2020, 17, 6767; doi:10.3390/iierph17186767

\begin{tabular}{|c|c|c|c|}
\hline & & & $\begin{array}{l}\text { due to lack of training institutions in } \\
\text { the SADC region. }\end{array}$ \\
\hline [13] & $\begin{array}{l}\text { Review of Occupational Health and Safety } \\
\text { Organization } \\
\text { in Expanding Economies: The Case of Southern } \\
\text { Africa }\end{array}$ & $\begin{array}{l}\text { Occupational Health and Safety }(\mathrm{OH} \\
\& \text { S) regulatory frameworks and } \\
\text { service provision challenges. }\end{array}$ & $\begin{array}{l}\text { In the review, the study assessed the } \\
\text { arrangements of occupational health } \\
\text { and safety (OH\&S) governance. It } \\
\text { was found that OH\&S } \\
\text { administration responsibilities was } \\
\text { shared amongst different ministries } \\
\text { including Health, labour, mining and } \\
\text { agriculture. The authors concluded } \\
\text { that there is high discrepancy on the } \\
\text { management of OH \& } \mathrm{S} \text { amongst } \\
\text { ministries, leading to systems being } \\
\text { fragmented. }\end{array}$ \\
\hline [17] & $\begin{array}{l}\text { Current Status and the Future of Occupational } \\
\text { Safety and Health Legislation in Low- and Middle- } \\
\text { Income Countries }\end{array}$ & $\begin{array}{l}\text { Legislations governing } \mathrm{OH} \& \mathrm{~S} \text { in } \\
\text { low and middle income countries. }\end{array}$ & $\begin{array}{l}\text { In this study, it was found out that } \\
\text { there is insufficient legislation in } \\
\text { African situation to addresses the } \\
\text { need for a comprehensive OH \& S. } \\
\text { The study also provided an insight, } \\
\text { in which many legislations only } \\
\text { focus on chemical hazards, while } \\
\text { other important hazard categories }\end{array}$ \\
\hline
\end{tabular}

(1)

Review of Occupational Health and Safety

in Expanding Economies: The Case of Southern

agriculture. The authors concluded

that there is high discrepancy on the

management of $\mathrm{OH} \& \mathrm{~S}$ amongst .

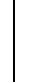

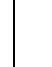

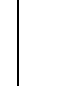

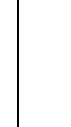

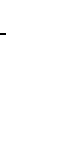


Peer-reviewed version available at Int. J. Environ. Res. Public Health 2020, 17, 6767; doi:10.3390/iierph17186767

\begin{tabular}{|c|c|c|c|}
\hline & & & $\begin{array}{l}\text { were left out. Other legislative } \\
\text { considerations such as gender } \\
\text { sensitive and equity were also } \\
\text { highlighted. }\end{array}$ \\
\hline [11] & $\begin{array}{l}\text { Occupational health challenges facing the } \\
\text { Department of Health: Protecting employees } \\
\text { against tuberculosis and caring for former } \\
\text { mineworkers with occupational health disease }\end{array}$ & $\begin{array}{l}\text { Provision of OHS to healthcare } \\
\text { workers. }\end{array}$ & $\begin{array}{l}\text { Adams and colleagues focused on } \\
\text { the provision of OHS to the } \\
\text { healthcare workers in the Western } \\
\text { Cape Province: South Africa. The } \\
\text { study found major gaps in the } \\
\text { provision of OHS. Health care } \\
\text { professionals received very little } \\
\text { services recording the highest score } \\
\text { of } 83 \% \text { only for the allocation of a } \\
\text { dedicated officer to coordinate the } \\
\text { OHS. However, most services such } \\
\text { as medical surveillance, biological } \\
\text { monitoring and risk assessment } \\
\text { achieved a score of below } 50 \% \text {. }\end{array}$ \\
\hline [18] & $\begin{array}{l}\text { Global Occupational Health: Current Challenges } \\
\text { and the Need for Urgent Action }\end{array}$ & $\begin{array}{l}\text { Provision of occupational, funding } \\
\text { and institutional capacity. }\end{array}$ & $\begin{array}{l}\text { Shortage of OHS experts across } \\
\text { countries as per the survey carried } \\
\text { out by the International Commission } \\
\text { on Occupational Health (ICOH). }\end{array}$ \\
\hline
\end{tabular}


Peer-reviewed version available at Int. J. Environ. Res. Public Healith 2020, 17, 6767; doi:10.3390/iierph17186767

\begin{tabular}{|c|c|c|c|}
\hline & & & $\begin{array}{l}\text { Only a third of the surveyed } \\
\text { countries had organized OHS for } \\
\text { about } 50 \% \text { of their workers. }\end{array}$ \\
\hline [19] & $\begin{array}{l}\text { Occupational health and safety in the African } \\
\text { region: situational analysis and perspectives }\end{array}$ & $\begin{array}{l}\text { Occupational Health and Safety } \\
\text { legislation, implementation, and } \\
\text { evaluation. }\end{array}$ & $\begin{array}{l}\text { About } 37 \% \text { of countries in Africa had } \\
\text { no access to legislations governing } \\
\text { OHS. Furthermore, it was found that } \\
\text { most of those countries with } \mathrm{OH} \& \mathrm{~S} \\
\text { legislations had not sufficient human } \\
\text { resources to facilitate the legislative } \\
\text { requirements. }\end{array}$ \\
\hline [20] & $\begin{array}{l}\text { Commentary on the Organisation of Occupational } \\
\text { Health and Safety in Southern Africa, the } \\
\text { International Labour Organization and Policies in } \\
\text { General }\end{array}$ & Provision of $\mathrm{OH} \& \mathrm{~S}$ in SADC region. & $\begin{array}{l}\text { In the commentary it was found that } \\
\text { there is a high disregard of } \mathrm{OH} \& \mathrm{~S} \\
\text { services across the SADC region. } \\
\text { Furthermore, more critical OH \& S } \\
\text { services operates without sufficient } \\
\text { competent personnel. Moreover, lack } \\
\text { of workplace surveillance is evident } \\
\text { and employers disregard employees' } \\
\text { rights to work in safer working } \\
\text { spaces. Ncube and Kanda also } \\
\text { reported that employers force }\end{array}$ \\
\hline
\end{tabular}


Peer-reviewed version available at Int. J. Environ. Res. Public Healith 2020, 17, 6767; doi:10.3390/iierph17186767

\begin{tabular}{|c|c|c|c|}
\hline & & & $\begin{array}{l}\text { employees to work under } \\
\text { unconducive working environments. }\end{array}$ \\
\hline$[6]$ & $\begin{array}{l}\text { Occupational Health Service Delivery in } \\
\text { South Africa }\end{array}$ & Provision of OHS in South Africa. & $\begin{array}{l}\text { In the study it was found that } \\
\text { occupational health services for } \\
\text { South African employees vary } \\
\text { according to the employment } \\
\text { categories. Employees in the public } \\
\text { sector are having a lesser organized } \\
\text { OHS service compared to those in the } \\
\text { private sector. The author further } \\
\text { emphasized that OHS services in the } \\
\text { public health system is hampered by } \\
\text { primary health care services. About } \\
94 \% \text { of the OHS in South Africa were } \\
\text { rendered by the private sector, with } \\
\text { just } 4 \% \text { contribution from the } \\
\text { government. Moreover, government } \\
\text { enforces legislations in protecting } \\
\text { workers in the private sector, while } \\
\text { they fail to provide the same } \\
\text { protection to their employees, }\end{array}$ \\
\hline
\end{tabular}


Peer-reviewed version available at Int. J. Environ. Res. Public Healith 2020, 17, 6767; doi:10.3390/iierph17186767

\begin{tabular}{|c|c|c|c|}
\hline & & & $\begin{array}{l}\text { despite employees in all sectors } \\
\text { being exposed to the same hazards. }\end{array}$ \\
\hline [21] & $\begin{array}{l}\text { Inequalities in occupational health services for } \\
\text { hospital government workers in South Africa. }\end{array}$ & $\begin{array}{l}\text { Organization of OHS in South } \\
\text { African health institution. }\end{array}$ & $\begin{array}{l}\text { The study found that about } 32 \% \text { of } \\
\text { the health facilities in South Africa } \\
\text { had OHS facilities onsite. About } 48 \% \\
\text { of the facilities had a dedicated } \\
\text { trained occupational health nurse. } \\
\text { Only } 9 \text { trained occupational medical } \\
\text { health practitioners were employed } \\
\text { in South African hospitals. }\end{array}$ \\
\hline [22] & $\begin{array}{l}\text { Collaborations in occupational health and safety } \\
\text { training and skill transfer. }\end{array}$ & $\begin{array}{l}\text { Limitations and gaps in the provision } \\
\text { of the occupational health and safety } \\
\text { services. }\end{array}$ & $\begin{array}{l}\text { It was reported that, most countries } \\
\text { in the SADC region experiences } \\
\text { shortage in critical position within } \\
\text { the OH\&S space. Moreover, it was } \\
\text { emphasized that the shortage can be } \\
\text { addressed by collaborative work, } \\
\text { where academic institutions support } \\
\text { one another in training OH\&S } \\
\text { professionals. }\end{array}$ \\
\hline [23] & Addressing the gaps in OH\&S field. & $\begin{array}{l}\text { Training of occupational hygiene } \\
\text { professionals. }\end{array}$ & $\begin{array}{l}\text { In the project it was indicated that } \\
\text { training of practitioner remains a }\end{array}$ \\
\hline
\end{tabular}

Inequalities in occupational health services for hospital government workers in South Africa.

rganization of OHS in South African health institution.

professionals. 
 \\ doi:10.20944/preprints202007.0570.v1 \\ Preprints (wrw.preprints.org) | NOT PEER-REVIEWED | Posted: 24 July 2020}

Peer-reviewed version available at Int. J. Environ. Res. Public Healith 2020, 17, 6767; doi:10.3390/iieroh17186767

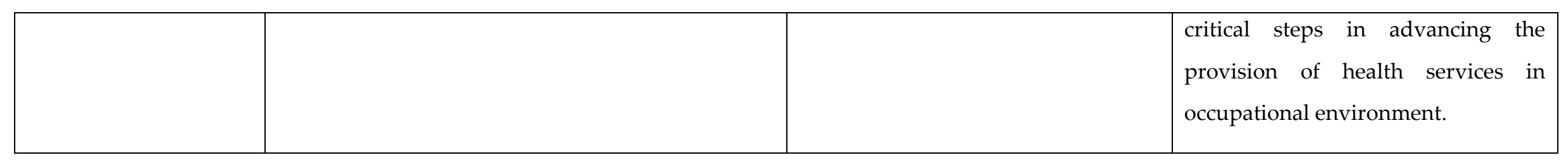




\subsection{Number of occupational health experts (Zambia, Lesotho, Mozambique and Malawi)}

In Table 2, a summary of OHS professionals from various ministries across the four project countries is provided. The results are tabulated based on the record as provided by heads of ministries responsible for occupational health administration in each country. From the results, it is evident that there is an increased shortage of occupational health professionals across the four project countries. Worthy to note that even countries that reported availability the professionals were not trained or accredited. Both Lesotho and Mozambique did not have an occupational hygienist or occupational health nurse. The percentages indicate the compliance status for each occupational health professional. Only Lesotho has managed to have a $100 \%$ allocation of OMPs against the national target. Of concern is the understanding of the ratio of occupational health professional vs the target serving populations. Clearly, we have not yet grasped the importance and contribution of OHS in the economy and alleviation of burden of diseases.

Furthermore, the expected number of health professionals at each category suggests that there might be a different understanding regarding the ratio of health professional per population. According to the world health organisation the ratio of 1: 1000 population is recommended as best practice. Looking at the projected figures as in Table 2, it maybe anticipated that the current allocation are not adequate [24].

Table 2: Number of $\mathrm{OH}$ experts per each country against the required number

\begin{tabular}{|c|c|c|c|c|c|c|c|c|}
\hline \multirow[t]{2}{*}{ Country } & \multicolumn{2}{|r|}{ OH } & \multicolumn{2}{|c|}{ OHN } & \multicolumn{2}{|c|}{ OMP } & \multicolumn{2}{|c|}{ OS } \\
\hline & Actual & $\begin{array}{c}\% \text { of allocated } \\
\text { Position }\end{array}$ & Actual & $\%$ of budget & Actual & $\%$ of budget & Actual & $\begin{array}{c}\% \text { of } \\
\text { budget }\end{array}$ \\
\hline Zambia & 8 & $40 \%$ & 2 & $11 \%$ & 4 & 33 & 0 & 0 \\
\hline Lesotho & 0 & 0 & 0 & 0 & 2 & $100 \%$ & 2 & $50 \%$ \\
\hline Malawi & 5 & $83 \%$ & 4 & $29 \%$ & 1 & $25 \%$ & 0 & 0 \\
\hline Mozambique & 0 & 0 & 0 & 0 & 1 & $3 \%$ & 4 & $4 \%$ \\
\hline
\end{tabular}

\subsection{Occupational health services Provision at primary health level in Zambia}

\subsubsection{Availability of occupational health services at primary health care level}

Using data extracted from the Zambian questionnaire respondents, it is evident that occupational health services are currently inadequate in the public health facilities/primary health care level. Table 3 , results shows that at the primary health care level, the inception of OHS is limited, with only $11 \%$ of the primary health care facilities offering $\mathrm{OH}$ services. 
Table 3: PHC services and OHS offered by the health institutions

\begin{tabular}{lccc}
\hline Facility type & Number & OHS offered & PHC services offered \\
\hline Hospital & $17(74 \%)$ & $2(11 \%)$ & $17(100 \%)$ \\
Clinic & $4(17 \%)$ & $0(0 \%)$ & $4(100 \%)$ \\
OHS Center & $2(9 \%)$ & $2(100 \%)$ & $0(0 \%)$ \\
\hline \hline
\end{tabular}

\subsubsection{Training on occupational health services amongst Zambian doctors}

Most of the doctors, (91\%), did not have training in occupational health while only $9 \%$ had such training. This finding is a cause of concern as a remarkably high proportion of those practicing is not trained.

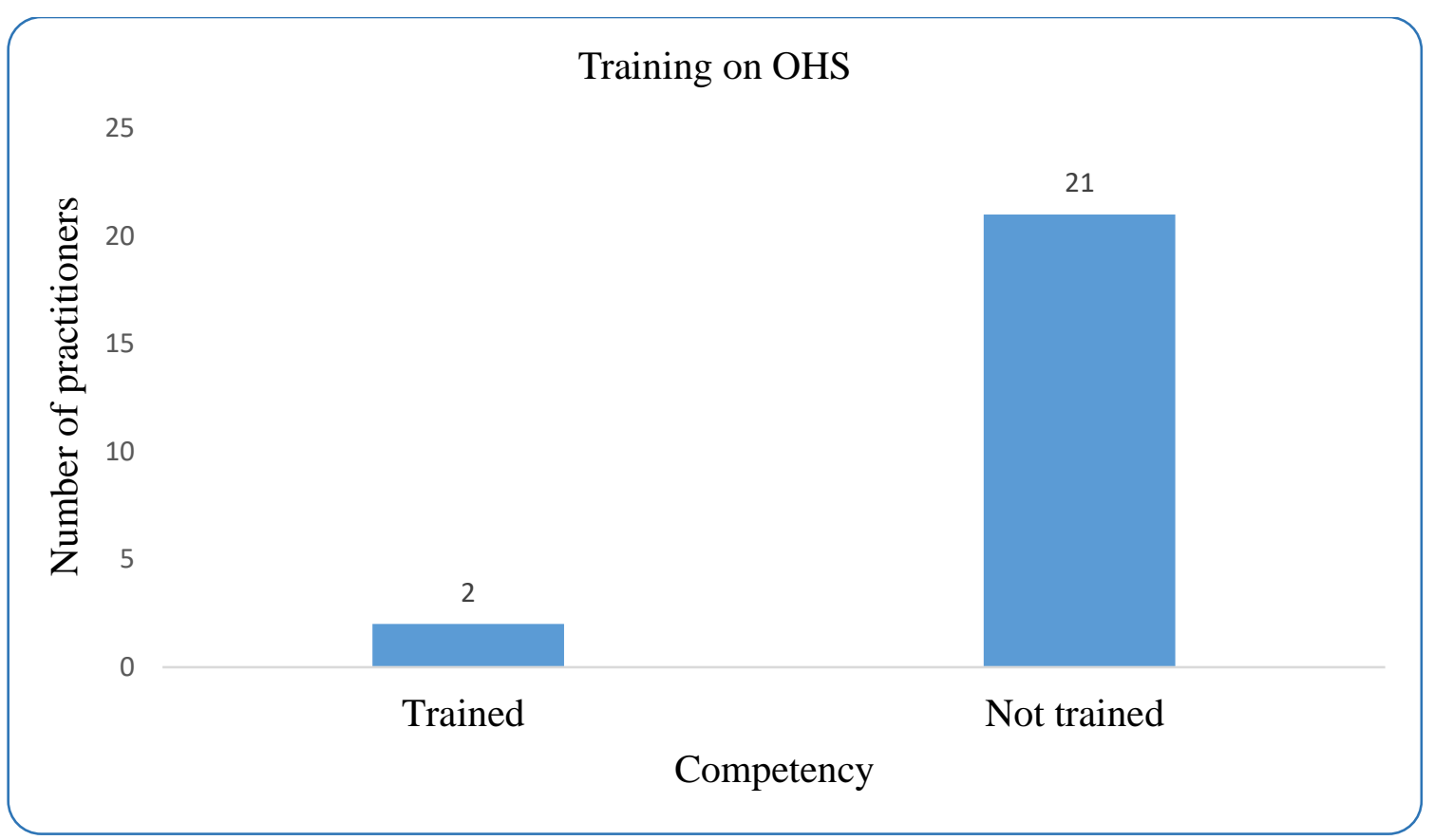

Figure 1: Number of practitioners trained in $\mathrm{OH}$ services

\subsubsection{Health promotion and prevention measures available and practiced}

The results in Table 4 show that pre-placement medical examinations were offered by most institutions. Most of the medical examinations that were done were not risk based. This is evidenced by the low number of available risk assessment services that stood at (48\%). Exit medical examinations were only available to a limited extent as only $33 \%$ of the respondents indicated the availability of such.

Table 4: Availability of exposure or disease prevention services

Risk assessment Pre-placement Medicals Periodic Medicals $\quad$ Exit Medicals




\subsubsection{Diagnosis services available}

The results in Table 5 show that most institutions in Zambia do not offer comprehensive OHS as evidenced by the low proportions of audiometry $(24 \%)$ and spirometry ( $14 \%)$ services offered. However, a greater proportion of the respondents, $75 \%$, indicated that vision testing was done in most of the institutions. Blood lead measurements were available in $48 \%$ of the institutions

Table 5: Available diagnostic services at various institutions in Zambia

\begin{tabular}{cccc}
\hline \hline Audiometry & Spirometry & Vision testing & Blood lead levels \\
\hline 5 & 3 & 16 & 10 \\
$\mathbf{2 4 \%}$ & $\mathbf{1 4 \%}$ & $\mathbf{7 6 \%}$ & $\mathbf{4 8 \%}$ \\
\hline \hline
\end{tabular}

\subsubsection{Treatment services and training}

The results in Table 6 show that primary health care services are the predominant services offered by health institutions while only $33 \%$ offered pneumoconiosis services. TB and HIV services were offered by most health institutions as evidenced by $95 \%$ of the respondents who indicated so.

Table 6: Available primary and occupational health services in Zambia PHC services TB and HIV services Pneumoconiosis/ Silicosis Trained on $\mathrm{OH}$

\begin{tabular}{cccc}
\hline 19 & 20 & 7 & 2 \\
$\mathbf{9 0 \%}$ & $\mathbf{9 5 \%}$ & $\mathbf{3 3 \%}$ & $\mathbf{1 0 \%}$ \\
\hline \hline
\end{tabular}

\subsubsection{Health promotion services}

Most respondents, $86 \%$, indicated that their institutions offered health promotion services while $76 \%$ offered rehabilitation services. In terms of health promotion and rehabilitation, there is a noticeable improvement which might be aided by the fact that, these services are integrated into primary health care services. 


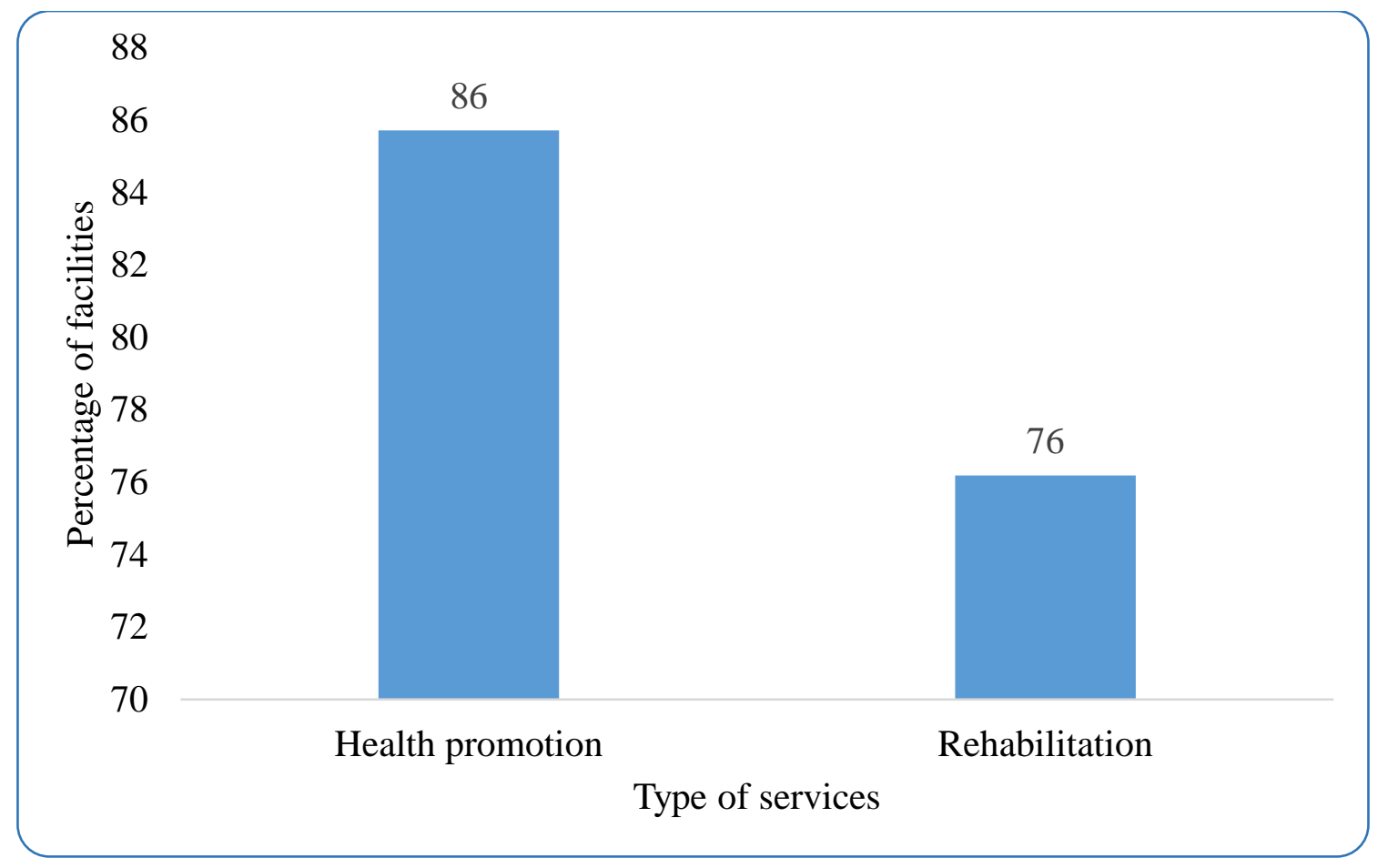

Figure 2: Availability of non-treatment based OHS

\section{Discussion}

From the literature review, only 10 research articles and 2 technical reports were relevant to the study. This points towards the paucity of published research resources in the field of occupational health in Southern Africa as asserted by Moyo et al.[13]. The literature review findings and results of enquiries with heads of ministries in the four study countries are in concordance with the fact that SADC has gross inadequacies in access to OHS and availability of appropriately qualified occupational health personnel across the medical, nursing, occupational hygiene and safety disciplines. Shortage of trained OHS professionals $[10,18,21]$ and poor OHS legislative frameworks $[17,19]$ are major issues confronting SADC. This standing is further corroborated by the findings of this study where most Zambian doctors, 91\%, lack training in occupational health but are the key providers of health services in primary health care centres. The enquiry from the heads of ministries of health revealed that the four countries are inadequately staffed, and where such positions for occupational health staff were allocated, like in Lesotho, the numbers were way too low for an effective occupational health program at the national level. From the study findings, it is noticeably clear that the study countries lack the framework and capacity to deliver comprehensive occupational health and safety issues. Despite the establishment of occupational health service centres in Southern Africa by the Global Fund TB in the Mining Sector project, [13] there still remains a big gap with respect to human resources capacity development in the field of occupational health. There is still a need to build capacity that matches the available occupational health facilities in the four SADC countries. The study results show that most Zambian 
doctors noted that their institutions provided predominantly primary health services with very few institutions providing extremely limited OHS.

This research reveals the gross inadequacies of OHS provision in the four study countries. It further highlights the lack of integration of OHS into primary health care service centres. Lack of adequate regulatory frameworks in occupational health are major challenges emerging from the findings of our study.

\section{Conclusion}

The findings of our study confirm the inadequacies of access to occupational health services in the four SADC countries. It brings to fore the urgent need for the provision of OHS at the primary health care level across the four countries under study. It is key to note that poor and near absent comprehensive occupational health services regulatory frameworks could be one of the chief impediments to the development of occupational health services in the region. The study findings conclude that OHS remain greatly constrained in the four study countries with however a great potential of expanding such services through the transformation of OHS regulatory frameworks and capacity development in the field of occupational health. Since the primary health services offer the first point of access to OHS, it remains a key strategic approach to interface the two services. It is our strong recommendation that building capacity in occupational health and integrating them into primary health services backed by comprehensive OHS legislation, remains the key approach to increased and improved access to OHS across SADC.

Author Contributions: Daniel Masekameni conceptualized and prepared the manuscript. Dingani Moyo worked alongside with Daniel to conceptualise the paper and writing up. Norman developed the methodology for data analysis. He further analyzed the data and assisted in the editing of the manuscript. Chimwewe edited the manuscript and validated the methodology for data collection and analysis.

Acknowledgments: This work was done in collaboration with several individuals and institutions. We are grateful to the Zambian Centre of Excellence for hosting a regional training and assisting in data collection during the training period. Gratitude is extended to Dr Fwasa Singogo from the department of health in Zambia for his continued excellent support during the course of the project. Several ministries in the four project countries are also acknowledged for their cooperation and participation in data collection/ provision which made it possible to write-up this project.

Conflicts of Interest: There is no conflict in any part of this work.

\section{References}

1. van Dijk, F.; Buijs, P. Manual for primary health care on Basic Occupational Health Services. 
Encouraging publication from India, focused on informal occupations. Asia Pac. Fam. Med. 2017, 16, 2-5, doi:10.1186/s12930-017-0032-8.

2. Lim, S.S.; Vos, T.; Flaxman, A.D.; Danaei, G.; Shibuya, K.; Adair-Rohani, H.; Amann, M.; Anderson, H.R.; Andrews, K.G.; Aryee, M.; et al. A comparative risk assessment of burden of disease and injury attributable to 67 risk factors and risk factor clusters in 21 regions, 1990-2010: A systematic analysis for the Global Burden of Disease Study 2010. Lancet 2012, 380, 2224-2260, doi:10.1016/S0140-6736(12)61766-8.

3. WHO Connecting Health and Labour: Bringing together occupational health and primary care to imrpove the health of working people. Glob. Conf. 'Connecting Heal. Labour What Role Occup. Heal. Prim. Heal. Care' 2012, 1-12.

4. Wang, Y.; Xue, J.; Cheng, S.; Ding, Y.; He, J.; Liu, X.; Chen, X.; Wang, Y.; Feng, X.; Xia, Y. The relationship between manganism and the workplace environment in China. Int. J. Occup. Med. Environ. Health 2012, 25, 501-505, doi:10.2478/s13382-012-0049-z.

5. Donnelly, C.; Brenchley, C.; Crawford, C.; Letts, L. The integration of occupational therapy into primary care: A multiple case study design. BMC Fam. Pract. 2013, 14, doi:10.1186/1471-2296-1460.

6. Michell, K.E. Occupational Health Service Delivery in South Africa. Workplace Health Saf. 2012, 60, 63-66, doi:10.1177/216507991206000205.

7. Bloch, K.; Johnson, L.F.; Nkosi, M.; Ehrlich, R. Precarious transition: A mortality study of South African ex-miners. BMC Public Health 2018, 18, 1-10, doi:10.1186/s12889-018-5749-2.

8. Ehrlich, R.; Montgomery, A.; Akugizibwe, P.; Gonsalves, G. Public health implications of changing patterns of recruitment into the South African mining industry, 1973-2012: A database analysis. BMC Public Health 2017, 18, 1-12, doi:10.1186/s12889-017-4640-x.

9. Coomer, K.; Houdmont, J. Occupational health professionals' knowledge, understanding and use of work ability. Occup. Med. (Chic. Ill). 2013, 63, 405-409, doi:10.1093/occmed/kqt070.

10. Moyo, D.; Zungu, M.; Erick, P.; Tumoyagae, T.; Mwansa, C.; Muteti, S.; Makhothi, A.; Maribe, K. Occupational health and safety in the Southern African Development Community. Occup. Med. (Chic. Ill). 2017, 67, 590-592, doi:10.1093/occmed/kqx071.

11. Adams, S.; Ehrlich, R.; Ismail, N.; Quail, Z.; Jeebhay, M.F. Occupational health challenges facing the Department of Health: protecting employees against tuberculosis and caring for former mineworkers with occupational health disease. South African Heal. Rev. 2012, 67-82.

12. Nilvarangkul, K.; Phajan, T.; Inmuong, U. Exploring Challenges to Primary Occupational Health Care Service for Informal Sector Workers. Prim. Heal. Care Open Access 2016, 06, doi:10.4172/2167-1079.1000245.

13. Moyo, D.; Zungu, M.; Kgalamono, S.; Mwila, C.D. Review of Occupational Health and Safety Organization in Expanding Economies: The Case of Southern Africa. Ann. Glob. Heal. 2015, 81, 495-502, doi:10.1016/j.aogh.2015.07.002.

14. Naidoo, R.; Kessy, F.; Mlingi, L.; Petersson, N.; Mirembo, J. Occupational Health and Safety in the Informal Sector in Southern Africa : the WAHSA project in Tanzania and Mozambique. Occup. Heal. South. Africa 2009, 15, 46-50.

15. Reho, T.T.M.; Atkins, S.A.; Talola, N.; Viljamaa, M.; Sumanen, M.P.T.; Uitti, J. Frequent attenders in occupational health primary care: A cross-sectional study. Scand. J. Public Health 2019, 47, 2836, doi:10.1177/1403494818777436.

16. WHO Integration of workers ' health in strategies for primary health care. 2009. 
17. Ncube, F.; Kanda, A. Current Status and the Future of Occupational Safety and Health Legislation in Low- and Middle-Income Countries. Saf. Health Work 2018, 9, 365-371, doi:10.1016/j.shaw.2018.01.007.

18. Rantanen, J.; Lehtinen, S.; Iavicoli, S. Occupational health services in selected international commission on occupational health (ICOH) member countries. Scand. J. Work. Environ. Heal. 2013, 39, 212-216, doi:10.5271/sjweh.3317.

19. Africano, R.I.O.R. Report of the Regional Director Paragraphs PRIORITY INTERVENTIONS 35 - 41. 2004.

20. Ncube, F.; Kanda, A. Commentary on the organisation of occupational health and safety in Southern Africa, the international labour organization and policies in general. Ann. Glob. Heal. 2018, 84, 500-503, doi:10.29024/aogh.2333.

21. Moodley, P.P.; Bachmann, M.O. Inequity in occupational health services for government hospital workers in South Africa. Occup. Med. (Chic. Ill). 2002, 52, 393-399, doi:10.1093/occmed/52.7.393.

22. Khoza, N; Chamdimba C; Masekameni, D; Moyo, D. Regional collaborative initiatives to strengthen occupational health and safety training programmes in southern Africa. Occup. Heal. South. Africa 2020, 26, 42-43.

23. Khoza, Norman; Chamdimba, Chimwemwe; Mohamed, A.M.M.D. Report on the third regional community of practice on mine - regulation and o - ccupational health and safety, 21-22 September 2019. Occup. Heal. South. Africa 2019, 25, 197-198.

24. Poz, M.R.D.; Kinfu, Y.; Dräger, S.; Kunjumen, T. Counting health workers : definitions , data , methods and global results. 2007. 